\title{
DE
}

DE GRUYTER OPEN

\section{SPATIAL MODELING OF THE INFLUENCE OF MINING-GEOMETRIC INDICES ON THE EFFICIENCY OF MINING}

\section{MODELOWANIE PRZESTRZENNE WPLYWU WSKAŹNIKÓW GEOMETRYCZNYCH W GÓRNICTWIE NA WYDAJNOŚĆ PRAC WYDOBYWCZYCH}

The regularities of the changes of horizontal and sub-horizontal systems of cracks at different locations of Holovyne labradorite deposits are studied. The trend for stress to increase has been established in the quarry LLS “Optima” for Holovyne labradorite deposits in Volodar-Volynsk district, Zhytomyr region at the deepening of excavation. The duration of the working cycle of borehole drilling in a solid and cracked massif is calculated using a new method. The calendar planning method of mining is developed taking into account the dependence of drilling efficiency on horizontal and sub-horizontal systems of cracks.

Keywords: drilling efficiency, stone cracks pattern, drilling operation, calendar planning

W pracy badano regularne zmiany w powierzchniowych i podpowierzchniowych systemach spękań w różnych lokalizacjach złoża labradorytu wydobywanego w rejonie Hołowinu. W przypadku złoża labradoru z kamieniołomu LLS „Optima’ w regionie wołodarsko-wołyńskim oraz w rejonie Żytomierza, gdzie znacznie zwiększyła się głębokość wydobycia, zarejestrowane naprężenia wykazywały trend wzrostowy. Czas trwania cyklu wiercenia otworów w spękanym górotworze obliczono w oparciu o nową metodę. Opracowano kalendarz planowania prac wydobywczych z uwzględnieniem zależności wydajności wiercenia od układu powierzchniowych i podpowierzchniowych spękań.

Słowa kluczowe: efektywność wiercenia, system spękań, operacje wiercenia, planowanie kalendarza prac

* ZHYTOMYR STATE TECHNOLOGICAL UNIVERSITY,CHERNYAKHOVSKOGO STR., 103, ZHYTOMYR, UKRAINE, 10005

** INDUSTRIAL RESEARCH INSTITUTE FOR AUTOMATION AND MEASUREMENTS PIAP, JEROZOLIMSKIE 202, $02-486$ WARSAW, POLAND

*** INSTITUTE OF METROLOGY AND BIOMEDICAL ENGINEERING, WARSAW UNIVERSITY OF TECHNOLOGY, BOBOLI 8, 02-525 WARSAW, POLAND

\# Corresponding author: ikorobiichuk@piap.pl 


\section{Introduction}

The studies assess (Korobiichuk, 2013; Korobiichuk \& Iskov, 2013; Pershin \& Ulyakov, 2015; Moriya et al., 2015; Bakka \& Ilchenko, 1992; Karasev \& Bakka, 1997; Korobiichuk et al., 2016a, b; Sobolevskyi et al., 2016; Kosolapov, 1990) that drilling takes $50-80 \%$ of the total time of block stone mining. Thus, the increase of the time spent on drilling can considerably reduce the mining works efficiency and, as a result, it can reduce the overall profitability. The main criteria to evaluate the efficiency of mining are the cracks of a massif (Moriya et al., 2015; Bakka \& Ilchenko, 1992; Karasev \& Bakka, 1997; Korobiichuk et al., 2016a, b; Sobolevskyi et al., 2016; Kosolapov, 1990; Mosch et al., 2011; Caranassios et al., 2000; Rahimi \& Nygaard, 2015; Luodes \& Sutinen, 2011) which are estimated by means of different factors. Specific fracturing is one of the main factors which, along with a blocks output, is used to evaluate the deposit. Such approach allows evaluating the efficiency of mining process considering the output of prepared blocks. It also helps to plan the volumes of efficiently extracted product. A small error can occur but it depends on the method of block output forecasting; the known forecasting methods are numerous (Pershin \& Ulyakov, 2015; Moriya et al., 2015; Bakka \& Ilchenko, 1992; Karasev \& Bakka, 1997; Korobiichuk et al., 2016a, b; Sobolevskyi et al., 2016; Kosolapov, 1990; Mosch et al., 2011; Caranassios et al., 2000; Rahimi \& Nygaard, 2015). At the same time, considering the efficiency of mining complexes, the actual productivity is used as the main index, and it is the function of working cycle duration. An actual duration of a working cycle takes into account technological, technical, and natural factors. Therefore, a spatial modeling of the influence of mining-geometric factors on the efficiency of mining is considered to be a significant scientific and applied problem.

The factors evaluating the efficiency of a borehole drilling have been investigated in previous works (Sobolevskyi et al., 2016; Repin et al., 2014; Changgen et al., 2009; Franca \& Weber, 2004). But, as a rule, when studying the efficiency of a borehole drilling, the technical component is studied in the first place. Many scientific works dedicated to the calendar planning in the process of block stone mining are available (Sobolevskyi et al., 2016; Kosolapov, 1990; Mosch et al., 2011; Caranassios et al., 2000; Rahimi \& Nygaard, 2015). Quarry blocks recovery ratio is considered to be the main index of the mining process. This approach allows accurate forecasting of the blocks output without consideration of blocks categories; but it does not allow evaluating the forecasted efficiency of the output. Based on the factors mentioned above, the development of the method of mining works calendar planning should be considered. This method takes account of natural, technological and technical components of the block stone mining.

\section{Material and methods}

The results of the measurement of rock beds fissures were analyzed on the basis of the results of core boring, as well as the direct measuring of fissures in the quarry of LLS "Optima" in Holovyne labradorite deposits in Volodar-Volynsk district, Zhytomyr region.

Main features of labradorites of the given deposits are presented in table 1.

When making the direct measurement of fissures, the place of the fissure was surveyed with the help of theodolite T5 and a laser reel Leica Disto A-5. Grouping of fissures on the intervals which correspond to height marks of the bottom and upper boundaries of the terrace (192-186 m, 
Main features of Holovyne labradorite deposits

\begin{tabular}{|c|c|}
\hline \hline Features & Value \\
\hline Specific gravity, $\mathrm{kg} / \mathrm{m}^{3}$ & $2750-2840$ \\
\hline Water absorption, $\%$ & 0,21 \\
\hline Compressive strength, MPa & 162 \\
\hline Bending strength, MPa & 21 \\
\hline Abrasion, $\mathrm{g} / \mathrm{m}^{3}$ & 0,50 \\
\hline
\end{tabular}

185,99-180 m, 179,99-174 m) was carried out. There were obtained 84 values of fissure parameters. The results were processed by Surfer 13.2.438 software. The interpolation was done by kriging $(100 \times 100$ grid, linear transformations for time variable, spherical variogram model).

Regularities of sub-horizontal fissures orientation at Holovyne labradorite deposit were investigated considering the chart of cracks given in (Levytskyi \& Sobolevskyi, 2011). The coordinates of the center of sub-horizontal fissures and the angles of their decline were defined from the chart.

To evaluate the influence of sub-horizontal fissures on the drilling efficiency, the analysis using the following method was made: LLS "Optima" performed video filming of borehole drilling by a drilling machine COMANDO 110. The video filming was done by digital nonmetric camera Canon EOS 70 D which was attached to the tripod Slik Able 300 DX. The results of the preliminary calibration of nonmetric camera using the definite technique (Levytskyi \& Sobolevskyi, 2008) are given in the Fig. 1. The boreholes were drilled to the depth of $6,0 \mathrm{~m}$ with a step of $0,3 \mathrm{~m}$. The drilling of 11 boreholes was performed from a single permanent place of drilling machine dislocation.

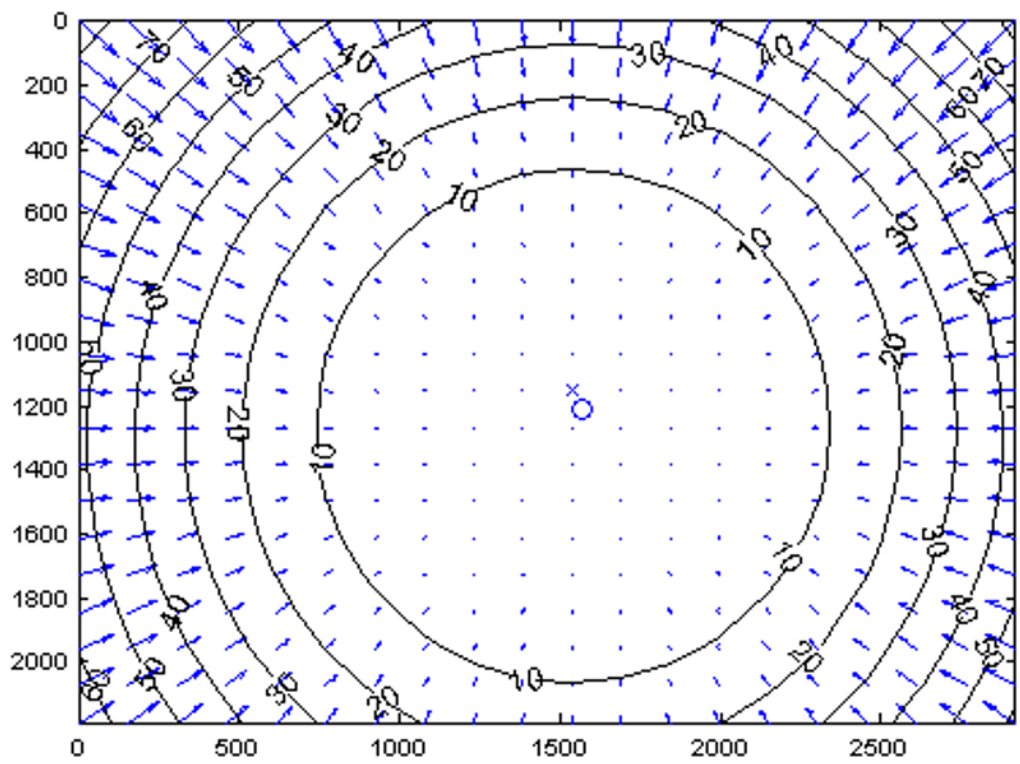

Fig. 1. Distortion model of calibrated optical system of a camera Canon EOS 70 D 
To increase the accuracy of estimation of drilling speed, the white graduations with intervals of $1 \mathrm{~m}$ were put on the bar (with the cone joining of 3,2 $\mathrm{m}$ long and with attached drilling conical head of $33 \mathrm{~mm}$ in diameter) (Fig. 2). Zero (0) marks the outermost part of a conical head. Drilling was performed in the cases when there were no bed cracks or when there were just two or three fissures.
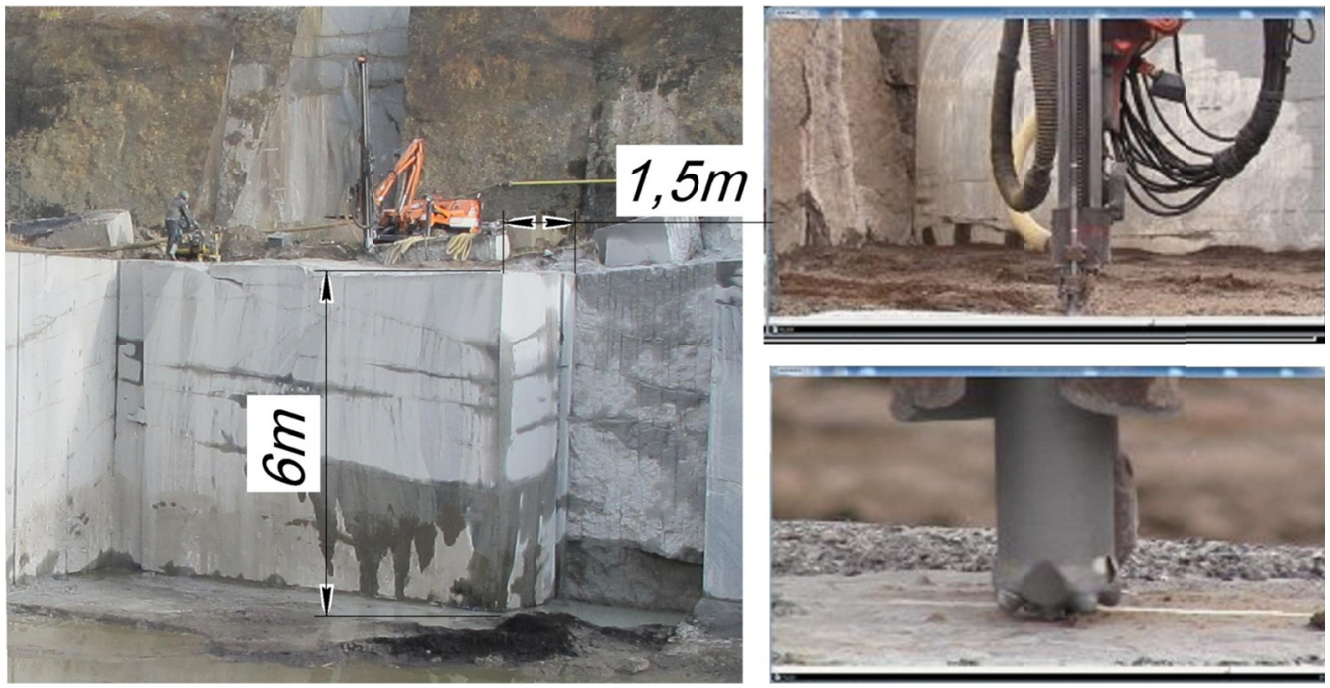

Fig. 2. Timing of borehole drilling by a drilling machine COMANDO 110

\section{Results and discussion}

The results of the changes of geospatial frequency of fissures at the horizons $+186 \mathrm{~m},+180 \mathrm{~m}$ and $+174 \mathrm{~m}$ are given in the Fig. 3 .

The analysis of obtained results shows that the fissures frequency tends to decrease with the increase in the horizon depth (the maximum frequency at the horizon 186 is 2.9; the maximum frequencies at the horizons 180 and 174 are, respectively, 1.3 and 0.51 ). The interesting fact is that each horizon has its individual localization of the maximum of fissures frequency. Thus, the maximum values of fissures frequency were detected in the eastern part of the horizon 186; the maximum values of fissures frequency at the horizon 180 were detected in its northern part; and at the horizon 174 these values were determined in the southern part. Zones of minimum fissures frequency at the horizons 186 and 180 coincide. These processes are observed in the south-western part of a deposit. Zone of minimum fissures frequency at the horizon 174 is located in diametrically opposite direction. Such geometry of the extremums of cracks is explained by the difficult interaction of tectonic processes with rotational component of the Earth crust movement.

The results of evaluation of changes in fissures frequency show that fluctuation of cracks frequency at the horizon +186 is from 0.4 to $2.9 \mathrm{pcs} . / \mathrm{m}$; at the horizon +180 is about $0.55-1.3 \mathrm{pcs} . / \mathrm{m}$; and at the horizon +174 is about $0.32-0.51 \mathrm{pcs} . / \mathrm{m}$. 


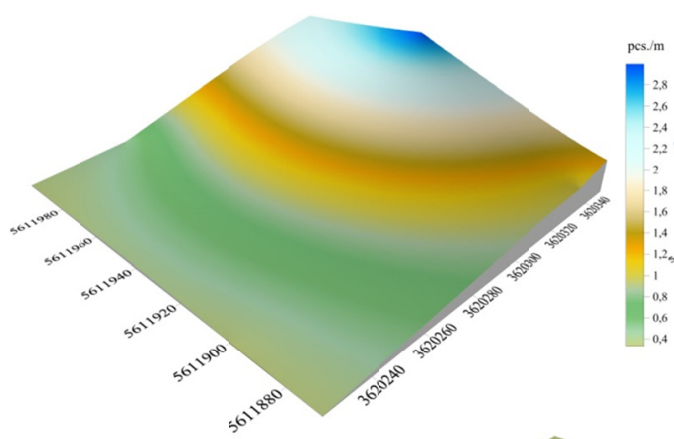

a)

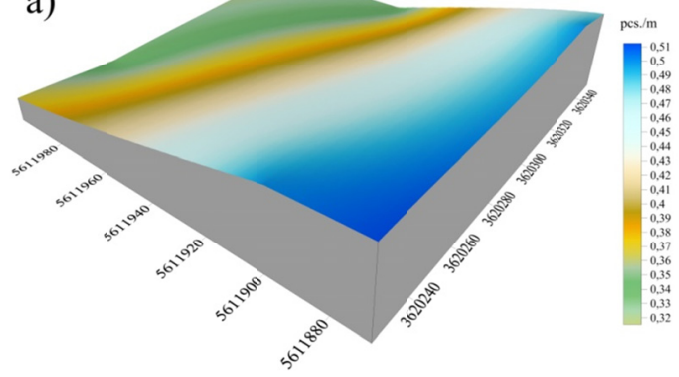

c)

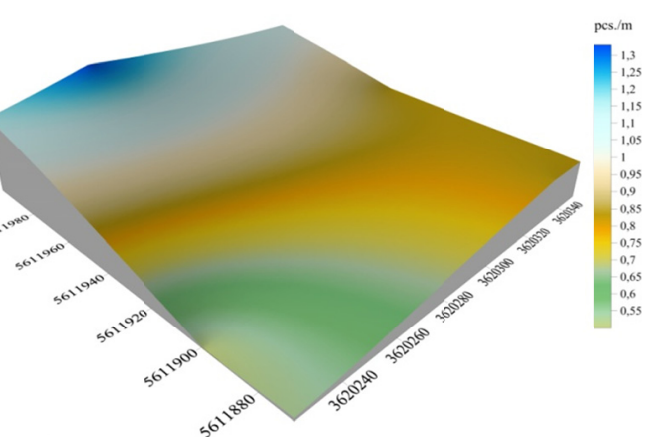

b)

Fig. 3. The evaluation of spatial distribution of frequency of cracks at different mining horizons: $\mathrm{a}$ - the average value for the depth marks $186 \mathrm{~m}$ (horizon 186), $\mathrm{b}$ - the average value for the depth marks $180 \mathrm{~m}$ (horizon 180), $\mathrm{c}$ - the average value for the depth marks $174 \mathrm{~m}$ (horizon 174)

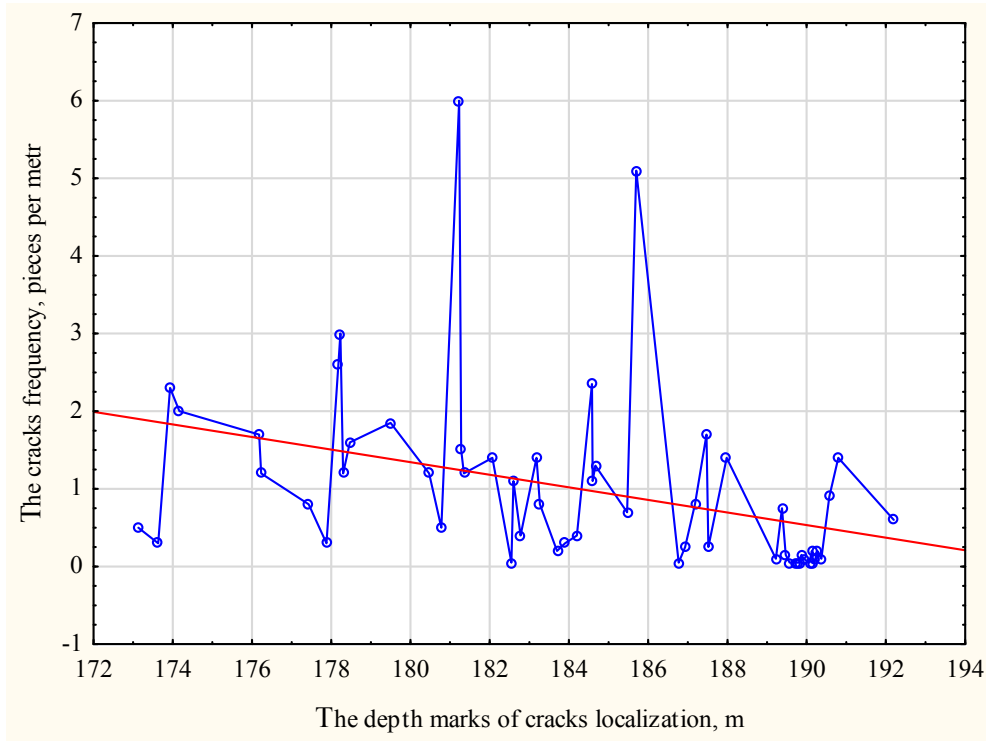

Fig. 4. The dependency graph of the cracks frequency on the depth marks of cracks localization 
The correlation analysis of the dependence of the fissures frequency on the depth indicates that the correlation relationship is not strong (it is characterized by the correlation coefficient 0.36 (Fig. 4)).

The relationship between the distance of fissures localization and the height marks of their localization in the condition of LLS "Optima" labradorite deposits in Volodar-Volynsk district, Zhytomyr region, was studied (Fig. 5). Statistical analysis of the results shows that the correlation relationship between the mentioned values is not strong (the correlation coefficient is 0.38 ).

The regularities of the orientation of sub-horizontal fissures at Holovyne labradorite deposits were studied. According to the results, a chart displaying the vectors of the increase of azimuths of sub-horizontal cracks spreading was built (Fig. 6). The results of the performed analysis of the mentioned chart prove that the southern direction dominates.

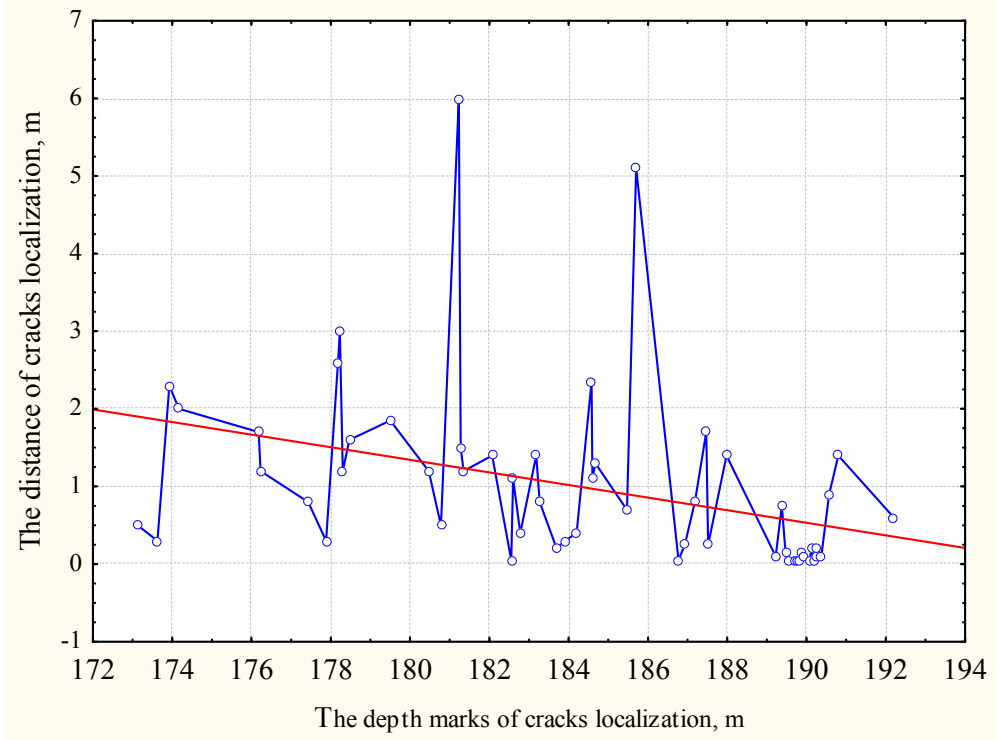

Fig. 5. The relationship between the distance of cracks localization and the height marks of their localization in the condition of LLS "Optima" labradorite deposits in Volodar-Volynsk district, Zhytomyr region

The open excavation is a graphic image on the vertical plane of the deposit structure. The open excavations are considered in the following terms: excavation depth equals $30 \mathrm{~m}$, ledge height is $10 \mathrm{~m}$. Fig. 7 shows the distribution of stresses which increase with depth. Stress on the excavation bottom is $15 \mathrm{MPa}$, and lateral (horizontal) stress reaches $3.5 \mathrm{MPa}$. The general trend is an increase in stress as the excavation deepens.

Fig. 8 shows a model of mining operations development at the deepening of excavation. An increase in stress from $15 \mathrm{MPa}$ to $20 \mathrm{MPa}$ is observed at the bottom of the quarry. The result of the new stress-strained state formed after the excavation are mechanical processes associated with the loss of lasting ability of surrounding rocks. This indicates an increase in stress in the array of block stone, which can lead to the formation of more cracks, closure of technological crevices and tools clamping. 


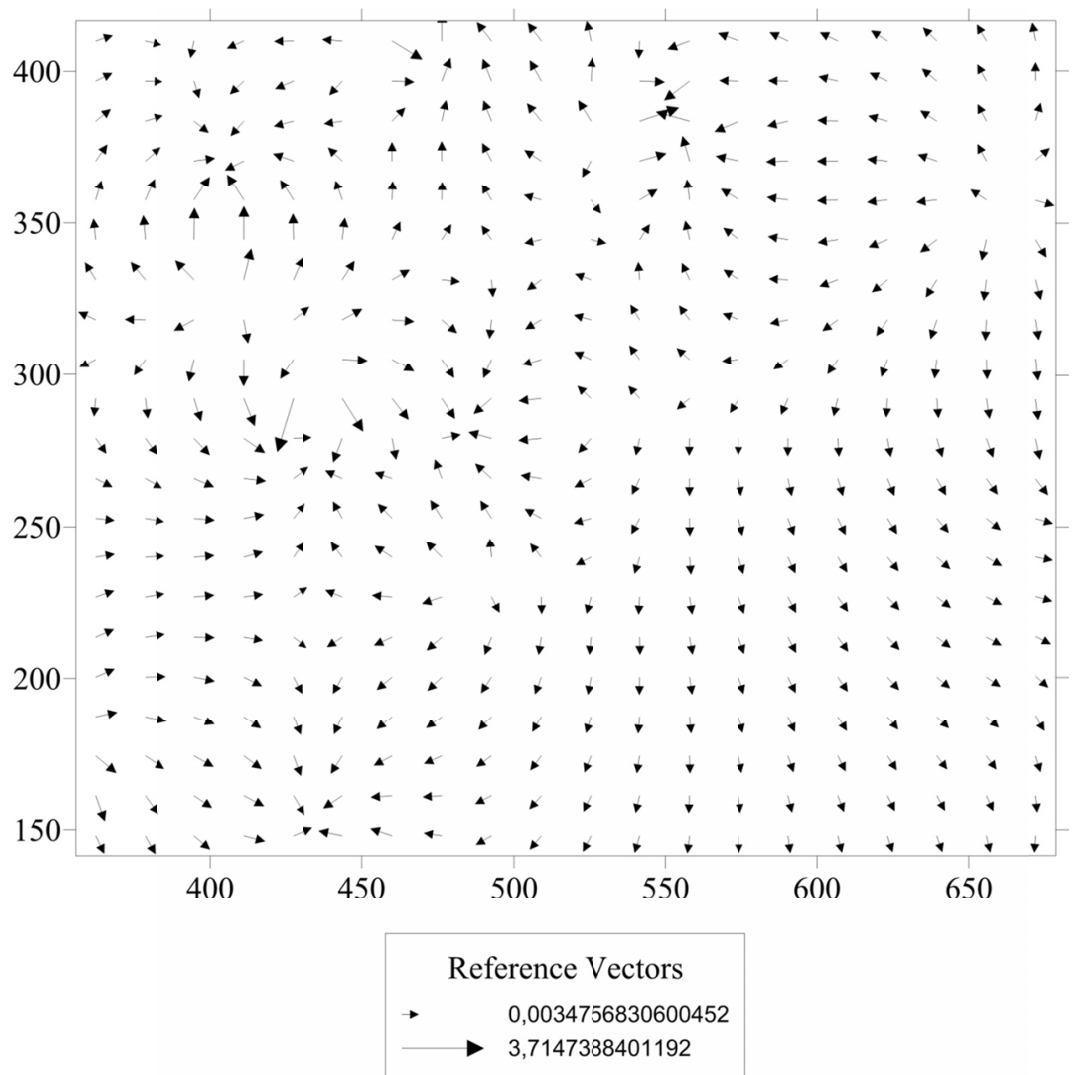

Fig. 6. The chart displaying the vectors of the increase in azimuths of sub-horizontal cracks spreading at Holovyne labradorite deposits

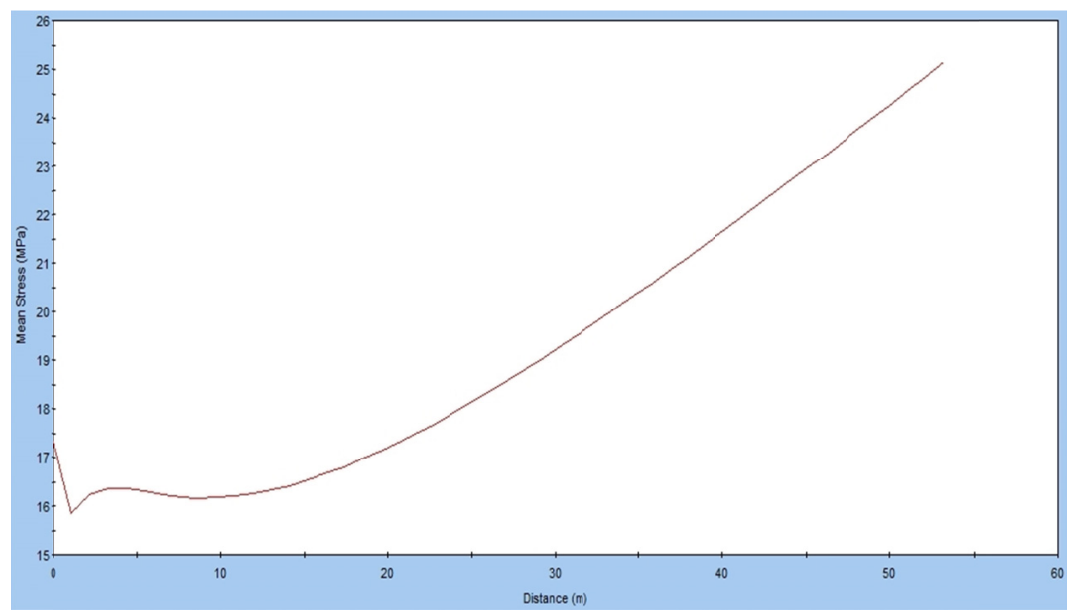

Fig. 7. Chart presenting the increase in main mechanical stresses with the increasing depth of excavation 


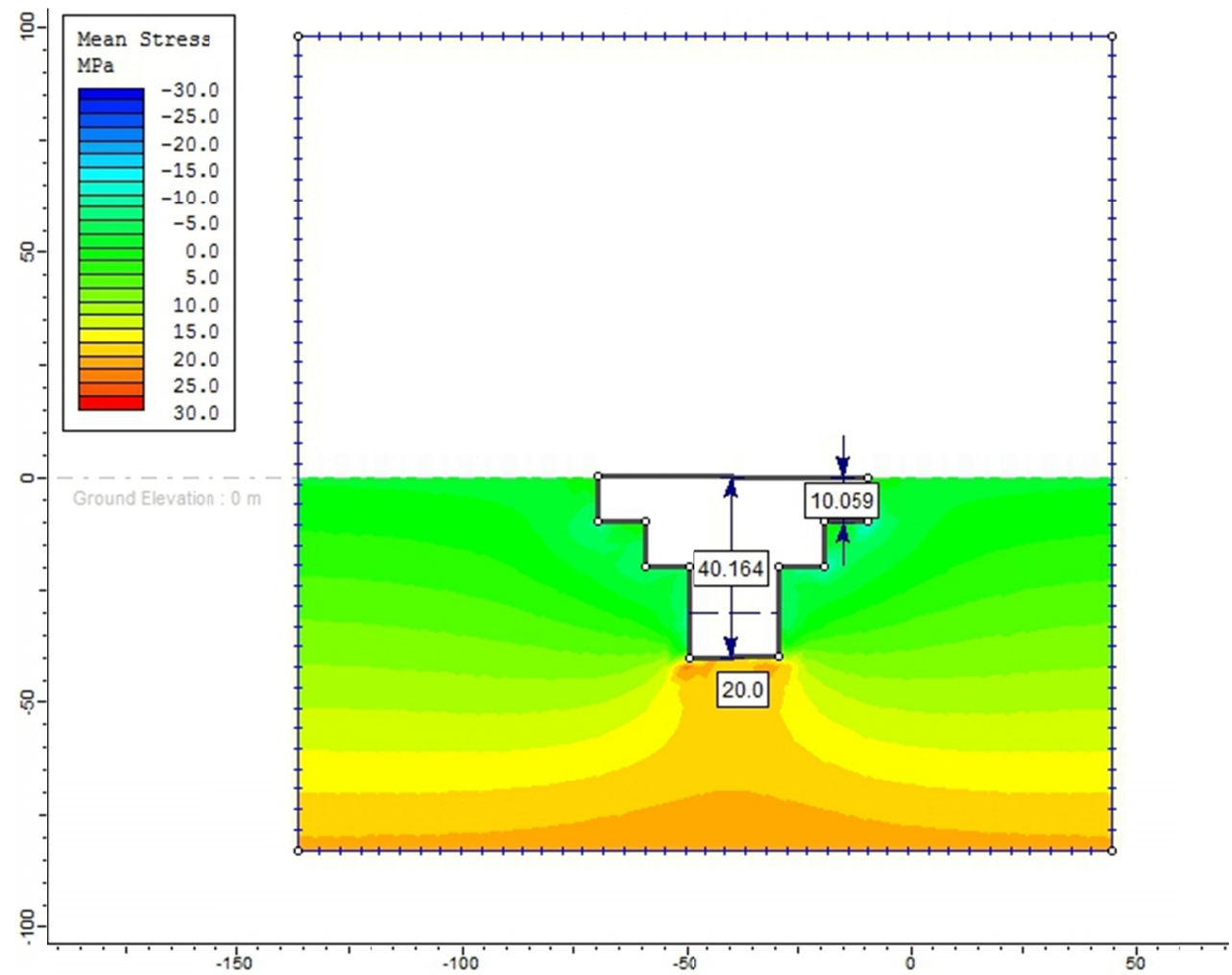

Fig. 8. Model of division of main mechanical stresses at the mining operations development in depth

The analysis of the production experience shows that the frequency of horizontal and subhorizontal cracks influences on the drilling efficiency. To evaluate the drilling efficiency several measurements of the duration of certain drilling operations were made according to the above mentioned method. Accomplished measurements allowed obtaining an analytical expression to calculate the duration of the working cycle for solid massif:

$$
T_{\text {c.m. }}=T_{i . s .}+T_{p r}+T_{\text {irs. }}+T_{3,0}+T_{\text {up } 3 m}+T_{\text {b.l. }}+T_{\text {low. } 3 m}+T_{3-6 m}+T_{\text {up } 6, \text { om }}+T_{\text {n.s. }}
$$

$T_{i s}$ - the time to install support in a vertical position, $T_{i s}=14.0 \mathrm{sec}$;

$T_{p r}$ — the time of predrilling to the depth of $0.3 \mathrm{~m}, T_{p r}=29.0 \mathrm{sec}$;

$T_{i r c}$ - the time to install rubber cup for trapping dust, $T_{i r c .}=12.0 \mathrm{sec}$;

$T_{3,0}$ - the time of drilling to the depth of $3 \mathrm{~m}, T_{3,0}=165.0 \mathrm{sec}$;

$T_{\text {up.3m }}$ - the time to lift the perforator from the depth of $3 \mathrm{~m}, T_{\text {up. } 3 \mathrm{~m}}=5.0 \mathrm{sec}$;

$T_{b . l .}$ - the time of bar lengthening, $T_{b . l .}=16.0 \mathrm{sec}$;

$T_{\text {low. } 3 \mathrm{~m}}$ - the time of lowering perforator to the depth of $3 \mathrm{~m}, T_{\text {low. } 3 \mathrm{~m}}=3.0 \mathrm{~m}$;

$T_{3-6 m}$ - the time to drill from 3-m depth to 6-m depth, $T_{3-6 m}=163.0 \mathrm{sec}$;

$T_{\text {up6,om }}-$ the time to lift the perforator from the depth of $6 \mathrm{~m}, T_{\text {up6,om }}=10.0 \mathrm{sec}$; 
$T_{n . s .}$ - the time of placing the machine at a new drilling site (the total time of the machine displacement within the range of a single monolith taking into account the time for the machine placing on a jack of $229 \mathrm{~s}$; considering the fact that 11 boreholes are made for each series, we can calculate the time for drilling of a single borehole), $T_{n . s .}=20.8 \mathrm{sec}$.

During the boreholes drilling, it was analytically substantiated that when a column drill meets a crack plane, the critical angle intercepting a single crack is about $2^{\circ}$; and it is $1^{\circ} 30^{\prime}$ when intercepting two or three cracks. The analysis of the angles of cracks decline and the ratio of these angles to the plane of drilling proves that the average angle of the meeting of a borehole with the plane of a bed crack is $3^{\circ}$. Thus, when meeting the bed fissures, it is considered reasonable to decrease the drilling speed value by $10 \%$ compared to the minimum one. Taking this fact into account, it is suggested to calculate the time of a single borehole drilling to the given depth $(6 \mathrm{~m})$ without the time for predrilling. The expression is the following for drilling machine COMANDO 110 with attached drilling conical head of $33 \mathrm{~mm}$ in diameter:

$$
T_{H}=\frac{H-h-l_{z} \cdot n}{v_{d . n o m .}}+\frac{n \cdot l_{z}}{v_{d . f}}
$$

$H$ - the depth of drilling, $\mathrm{m}$;

$h$ - the depth of predrilling, $h=0.3 \mathrm{~m}$;

$l_{z}$ - the zone length of the decrease in the drilling speed value when meeting with a fissure, $\mathrm{m}$;

$n$ - the quantity of sub-horizontal fissures which intercept the borehole, pcs.;

$v_{\text {d.nom. }}$ - the nominal value of the drilling speed, $\mathrm{m} / \mathrm{sec}$;

$v_{\text {d.f. }}-$ the value of the drilling speed when intercepting the fissure, $v_{\text {d.f. }}=(0,1-0,2) \times$ $\times v_{\text {d.nom. }}, \mathrm{m} / \mathrm{sec}$.

The expression (2) allows writing the expression (1) for the case when a borehole plane meets a fissure plane:

$$
T_{\text {c.f. }}=T_{i s}+T_{p r}+T_{\text {i.r.c. }}+T_{H}+T_{\text {up } 3 m}+T_{\text {b.l. }}+T_{\text {low. } 3 m}+T_{\text {up. } 6, \text { om }}+T_{\text {n.s. }}
$$

Correspondingly, the increase in the time of drilling, which is stipulated by the presence of fissures, can be calculated by the following expression:

$$
\Delta T=T_{\text {c.m. }}-T_{\text {c.f. }}
$$

According to the proposed method, the duration of a single borehole drilling for different intensity of cracks can be calculated.

Comparison of the cycle duration at a solid massif and a massif containing 8 cracks is showed in Fig. 9.

The comparison of the study results of cracks at different horizons and of the drilling process efficiency helped to calculate in absolute and percentage values the increase in duration of the working cycle of borehole drilling at horizons $186 \mathrm{~m}$ (Fig. 10), $180 \mathrm{~m}$ (Fig. 11) and $174 \mathrm{~m}$ (Fig. 12). 
The time to install support in a vertical position, sec

The time of predrilling to the depth of $0,3 \mathrm{~m}$, sec

The time to install rubber cup for trapping dust, sec

The time of drilling to the depth of $3 \mathrm{~m}$, sec

The time to lift the perforator from the depth of $3 \mathrm{~m}$, sec

The time for bar lengthening, sec

The time for lowering perforator to the depth of $3 \mathrm{~m}$, sec

The time to drill from 3-m depth to 6-m depth,sec

The time to lift the perforator from the depth of $6 \mathrm{~m}$, sec

The time to install boring rig in a new position, sec

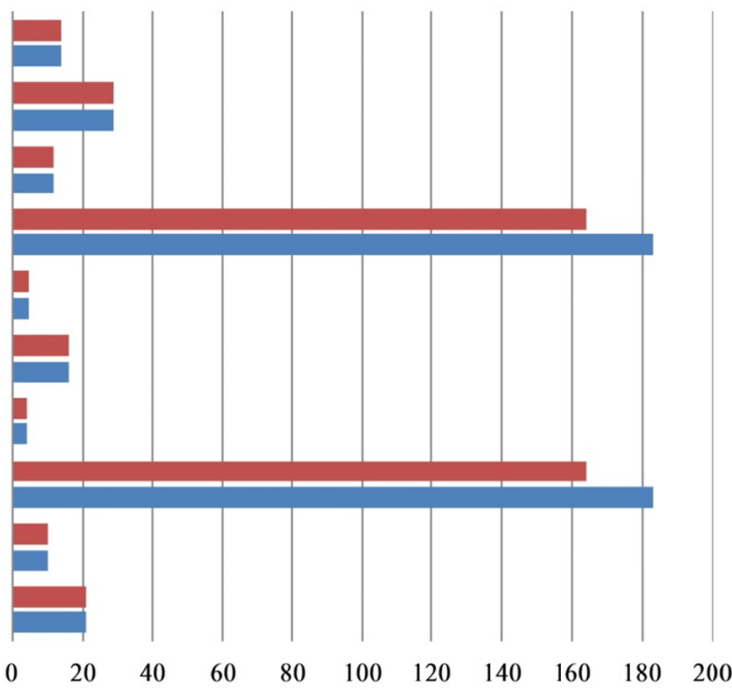

- Solid massif $\quad$ Massif containing 8 fissures

Fig. 9. Comparison of the cycle duration at a solid massif and a massif containing 8 fissures

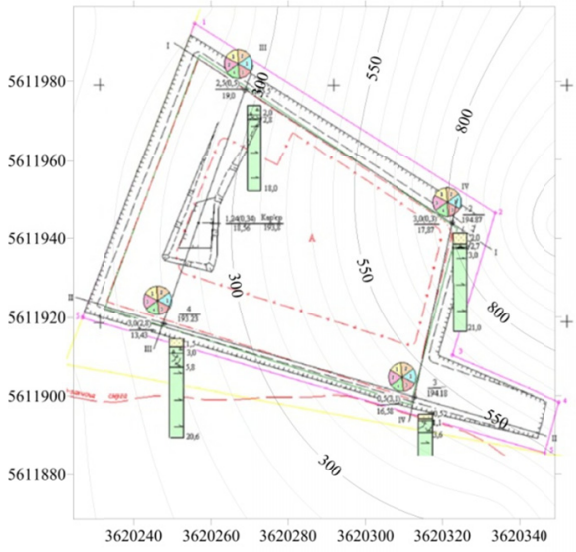

a)

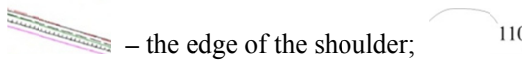

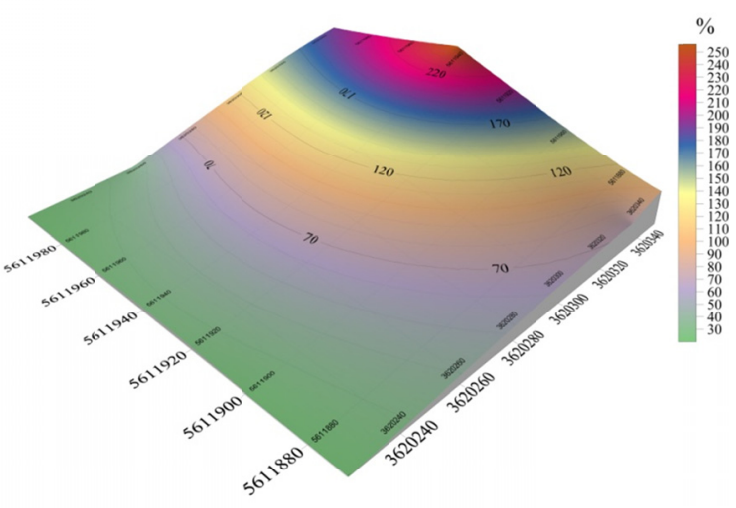

b)

Fig. 10. The increase in the time of drilling a single borehole in the conditions of LLS "Optima" at mining horizon 186: $\mathrm{a}$ - the time of drilling, sec; $\mathrm{b}$ - percentage values for the time of drilling a massif with one crack per meter and a massif containing other number of cracks, $\%$ 


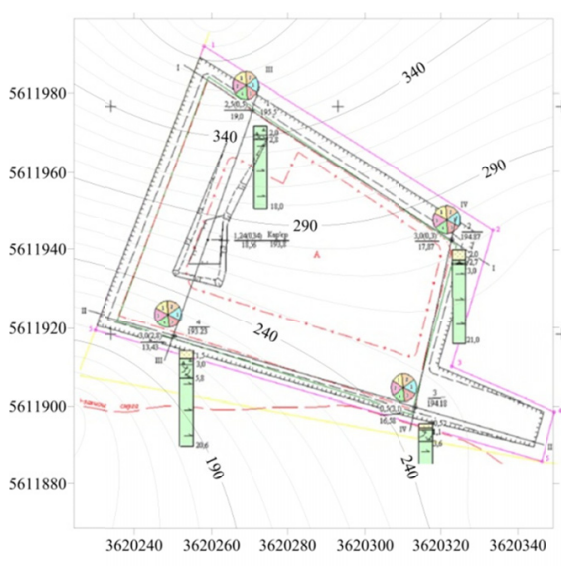

a)

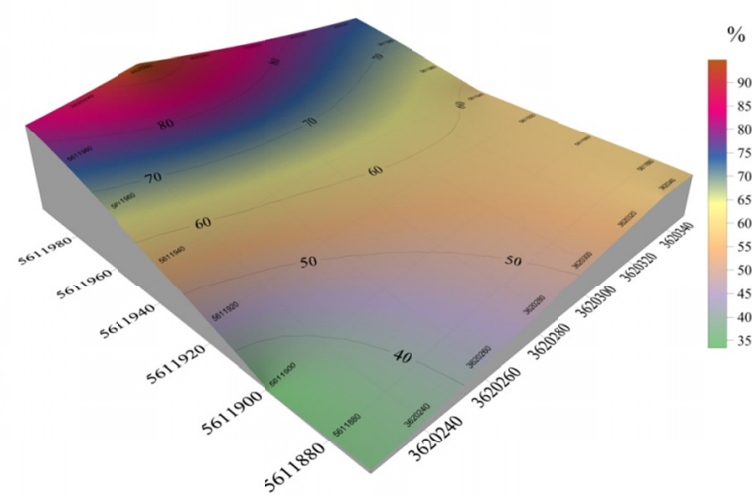

b)

- the edge of the shoulder; $\quad 110 \quad-$ the time of a single drilling to the given depth, sec

Fig. 11. The increase in the time of drilling a single borehole in the conditions of LLS "Optima" at mining horizon 180: $\mathrm{a}$ - the time of drilling, sec; $\mathrm{b}$ - percentage values for the time of drilling a massif with one crack per meter and a massif containing other number of cracks, $\%$

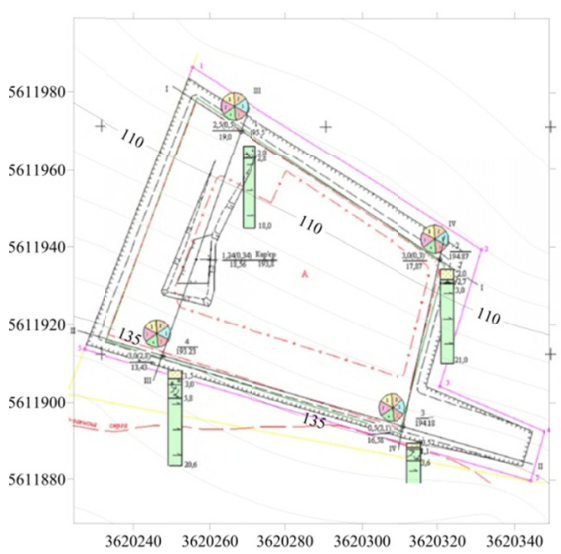

a)

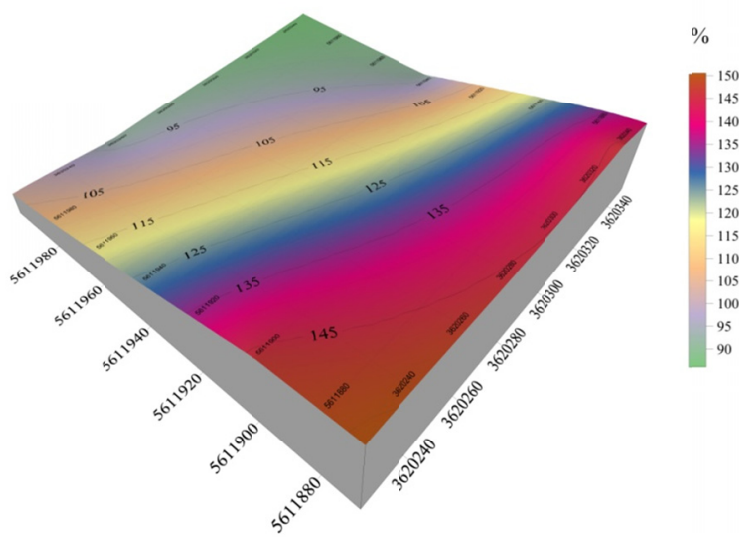

b)

\footnotetext{
- the edge of the shoulder; $\quad 110 \quad$ - the time of a single drilling to the given depth, sec
}

Fig. 12. The increase in the time of drilling a single borehole in the conditions of LLS "Optima" at mining horizons 174: $\mathrm{a}$ - the time of drilling, sec; $\mathrm{b}$ - percentage values for the time of drilling a massif with one crack per meter and a massif containing other number of cracks, $\%$ 


\section{Conclusion}

The analysis of the obtained results shows that the cracks frequency and the distance between cracks decreases with the increase in the horizon depth in the conditions of LLS "Optima" labradorite deposits in Volodar-Volynsk district, Zhytomyr region, though the tendency is insignificant. It is proved that each horizon has its individual localization of the extrema of cracks frequency.

The analysis of the regularities of spatial orientation of sub-horizontal cracks at Holovyne labradorite deposit showed that the increase in azimuth of sub-horizontal cracks spreading occurs, predominantly, in a southern direction.

The trend for stress to increase has been established in the quarry LLS "Optima" for Holovyne labradorite deposits in Volodar-Volynsk district, Zhytomyr region, with the increase of the excavation depth. The stress at the bottom of excavation reached $15 \mathrm{MPa}$, and lateral (horizontal) stress reached 3.5 MPa.

The comparative results of forecasting the increase in the duration of a single borehole drilling can help to optimize the calendar planning of drilling works and, thus, can increase the efficiency of a calendar planning of stripping (rocky overburden). The comparative analysis of the study of cracks at different horizons and of the drilling process efficiency helped to calculate the increase in the duration of the working cycle of borehole drilling at horizons of $186 \mathrm{~m}, 180 \mathrm{~m}$ and $174 \mathrm{~m}$ in absolute and percentage values. The results of the research allow accomplishing by-horizons division of deposits into separate technological zones depending on the forecasted efficiency of Hammer Percusive Drilling by drilling machine COMANDO 110.

\section{Acknowledgments}

The research project was supported by the Ministry of Education and Science of Ukraine (Project PK 108U009148). For the support of the research project the following people are gratefully acknowledged: prof. Kravetc Viktor (KPI), prof. Zhukov Sergii (KTU), prof. Tkachuk Konstiantin (KPI), Dr. Anui Kumar (CTU), Tcibulniak Andrii (Ltd. "Tiopol”), Lomakov Grigorii (Ltd. "Iskor"), Klevan Oleg (Ltd. "Temp-Buki”), Kostiuk Vitalii (Ltd. "Kirovgeologia"). Dr. Ruslan Sobolevskyi acknowledges the Erasmus Mundus Action 2 for supporting his scientific stay at Czech Technical University in Prague.

\section{References}

Bakka N., Ilchenko I., 1992. Facing stone. Geological and Industrial and Technological Evaluation Fields: Reference. [In:] Nedra, Moscow, 1-54.

Caranassios A., Tomi G., Senhorinho N., 2000. Geological modeling and mine planning for dimension stone quarries. [In:] Proc. Mine Planning and Equipment Selection, Balkema, Rotterdam, 39-45.

Changgen Bu, Yageo Qu, Zhigiang C., Baolin L., 2009. Numerical Simulation of Impact on Pneumatic DTH Hammer Percusive Drilling. Journal of Earth Science. 20, 868-878.

Demirdag S., Sengun N., Ugur I., Efe T., Akbay D., Altindag R., 2014. Variation of vertical and horizontal drilling rates depending on some rock properties in the marble quarries. International Journal of Mining Science and Technology, 24: 269-273.

Franca L., Weber H., 2004. Experimental and numerical study of a new resonance hammer drilling model with drift. [In:] Chaos, Solitons \& Fractals, 21 (4), 789-801. 
Karasev Y., Bakka N., 1997. Natural stone. Extraction of block stone wall: textbook. [In:] Nedra, St. Petersburg, 7-29.

Korobiichuk V., 2013. The influence of the height and width of the monolith that overturns on his destruction. [In:] Bulletin of Zhytomyr State Technological University, Zhitomir: ZDTU 1 (64), 134-138.

Korobiichuk V., Iskov S., 2013. Definition of rational method of extraction of stone monoliths for capital trenches. [In:] Technology audit and production reserves, Kharkiv, 5/1 (13), 12-16.

Korobiichuk I., Korobiichuk V., Iskov S., Nowicki M., Szewczyk R., 2016. Peculiarites of natural stone extraction technology with the help of diamond wire machines. 16th International Multidisciplinary Scientific GeoConference SGEM 2016, SGEM2016 Conference Proceedings, Book 1, 2, 649-656. DOI: 10.5593/SGEM2016/B12/S03.084.

Korobiichuk I., Korobiichuk V., Nowicki M., Shamrai V., Skyba G., Szewczyk R., 2016. The study of corrosion resistance of Pokostivskiy granodiorites afterprocessing by various chemical and mechanical methods. Construction and Building Material 114, 241-247. DOI: 10.1016/j.conbuildmat.2016.03.147.

Kosolapov A., 1990. The technology of extraction of facing stone. Publishing of Krasnoyarsk University, Krasnoyarsk, 1-52.

Levytskyi V., Sobolevskyi R., 2008. Analysis of stereophotogrammetric ways to capture the quarries of decorative stone. [In:] Abstracts of the $\mathrm{V}$ international conference of students, masters and post-graduate students "Modern problems of ecology and geotechnology", Zhitomir: ZDTU, 465-467.

Levytskyi V., Sobolevskyi R., 2011. Surveying and commercial digital photography of decorative stone blocks for the purpose of a precise definition of their scope and create the passport block production. [In:] Extraction, processing and use of natural stone, Magnitogorsk, 11, 41-45.

Luodes H., Sutinen H., 2011. Evaluation and modeling of natural stone rock quality using ground penetrating radar (GPR). [In:] Geological Survey of Finland, Special Paper, 49, 83-90.

Moriya H., Naoi M., Nakatani M., Aswegen G.V., Murakami O., Kgarume T., Ward A.K., Durrheim R.J., Philipp J., Yabe Y., Kawakata H., Ogasawara H., 2015. Delineation of large localized damage structures forming ahead of an active mining front by using advanced acoustic emission mapping techniques. International Journal of Rock Mechanics and Mining Sciences, 79, 157-165.

Mosch S., et al., 2011. Optimized extraction of dimension stone blocks. [In:] Environmental Earth Sciences, 63, $1911-1924$.

Pershin G., Ulyakov M., 2015. Enhanced dimension stone production in quarries with complex natural jointing. Journal of Mining Science, 51, 330-334.

Rahimi R., Nygaard R., 2015. Comparison of rock failure criteria in predicting borehole shear failure. International Journal of Rock Mechanics and Mining Sciences, 79, October 01, 29-40.

Repin A., Smolyanisky B., Alekseeev S., Popelyh A., Timonin V., Karpov V., 2014. Downhole High-Pressure Air Hammers for Open Pit Minin. Journal of Minig Science, 50, 929-937.

Sobolevskyi R., Korobiichuk I., Nowicki M., Szewczyk R., 2016. Using cluster analysis for planning mining operations on the granite quarries. 16th International Multidisciplinary Scientific GeoConference SGEM 2016, SGEM2016 Conference Proceedings, Book 2, 2, 263-270, DOI: 10.5593/SGEM2016/B22/S09.034. 